\title{
Exploration on the Educational Model of Applied Talents Cultivation in Universities of Guangdong- Hong Kong-Macao Greater Bay Area*
}

\author{
Xue Cheng \\ School of Logistics Management and Engineering \\ Zhuhai College of Jilin University \\ Zhuhai, China 519041
}

\author{
Xiaoyi Lin \\ School of Business Administration \\ Zhuhai College of Jilin University \\ Zhuhai, China 519041
}

\author{
Hanfei Jia \\ School of Public Management \\ Zhuhai College of Jilin University \\ Zhuhai, China 519041
}

\begin{abstract}
The development of the Guangdong-Hong KongMacao Greater Bay Area is both an opportunity and a challenge for the development of innovative education of colleges and universities in Guangdong Province. At present, the colleges and universities in Guangdong Province face many challenges in the term of innovative education. This article makes the analysis from the shortage of innovative education teachers, outdated education models, weak awareness of innovation and entrepreneurship among college students, and inadequate university cooperation in colleges and universities of Guangdong Province, and puts forward relevant opinions and suggestions.
\end{abstract}

Keywords-colleges and universities; innovative education; problems; countermeasures

\section{INTRODUCTION}

The Guangdong-Hong Kong-Macao Greater Bay Area is one of the regions with the highest degree of openness and the strongest economic vitality in China. It has obvious location advantages, concentrated innovation factors, and a leading international level. Compared with other bay areas, it has obvious competitive advantages. On February 18, 2019, the Central Committee of the Communist Party of China and the State Council issued the "Outline of the Development Plan for the Guangdong-Hong Kong-Macao Greater Bay Area". The "Outline" made the future development plan for the Guangdong-Hong Kong-Macao Greater Bay Area, so as to build the Guangdong-Hong Kong-Macao Greater Bay Area a world-class city cluster. Looking at the international first-class bay areas such as San Francisco Bay Area, the New York Bay Area, and the Tokyo Bay Area, it is clear that encouraging innovation and entrepreneurship, cultivating

*Fund: Provincial key platforms and major scientific research projects of Guangdong universities in 2018: Research on innovative education of Guangdong universities in the Guangdong-Hong Kong-Macao Greater Bay Area (Project No. 2018WQNCX256) innovative talents, and improving economic vitality are one of the important reasons for the success of the bay area. This shows that innovation drive is an important engine of economic and social development in the bay area. For Guangdong-Hong Kong-Macao Greater Bay Area, the adequacy of innovation vitality will directly affect the economic development speed and quality of the Greater Bay Area. General Secretary Jiang Zemin once pointed out at the National Science and Technology Conference: "Innovation is the soul of a nation's progress and the inexhaustible motive force for the country's prosperity and development. If independent innovation capabilities are not improved, it is difficult to get rid of technological backwardness by relying solely on technology introduction. A nation without innovation ability can hardly stand in the forest of advanced nations in the world." Similarly, if the Guangdong-Hong Kong-Macao Greater Bay Area is to become a world-class bay area, it must have certain innovative talents. College students are the group with the most active thinking and strong sense of innovation and entrepreneurship, and are the backbone of the cultivation and storage of innovative talents. Therefore, accelerating innovation education of colleges and universities in Guangdong province, cultivating innovative talents, and creating an innovation platform are of great practical significance for the successful realization of the development goals of the Guangdong-Hong Kong-Macao Greater Bay Area.

In the new situation, China attaches special importance to the cultivation of innovative talents, and puts forward the strategic deployment of independent innovation capabilities to build an innovative country. The report of the 19th Party Congress will accelerate the construction of an innovative country as a national development strategy in the new era. The position and role of talented personnel training in the development strategy of the party and the country are more prominent. And the cultivation of innovative talents lies in 
education. Education is an important cradle for cultivating innovative spirit and innovative talents. The "Central Committee of the Communist Party of China and the State Council's Decision on Deepening Education Reform and Comprehensively Promoting Quality Education" clearly states the training goals of higher education: "Higher education must attach importance to the cultivation of college students' innovative ability, practical ability and entrepreneurial spirit, and generally improve the humanistic quality and scientific quality of college students." To achieve the training goals of higher education, it is necessary to implement innovative education, cultivate the spirit of innovation of college students, and stimulate the innovative ability of college students. As one of the main bodies of the national innovation system, universities shoulder important historical missions and responsibilities in the cultivation of innovative talents. In the context of the development of the Guangdong-Hong Kong-Macao Greater Bay Area, Guangdong universities must attach great importance to and fully understand the importance of cultivating innovative talents, and strive to cultivate more high-quality, top-notch innovative talents.

\section{PROBLEMS EXISTING IN INNOVATION EDUCATION OF Colleges AND Universities IN GUANGDONG PROVINCE}

\section{A. Lack of Teachers for Innovation Education}

First, in recent years, many colleges and universities in Guangdong Province have generally expanded the scale of enrollment, and the number of students has increased rapidly. However, the number of teachers in colleges and universities has not changed much, resulting in a serious imbalance in the ratio of teachers and students. There are many universities where innovation and entrepreneurship courses are taught by professional teachers or counselors. These teachers lack the ability of innovation and entrepreneurship education, so that they fail to meet the requirements of training innovative talents. Second, although colleges and universities have recruited a large number of teachers with high-level academic qualifications, there is still a serious shortage of teachers with innovative spirit, innovative ability and innovative experience. Many highly educated teachers have rich theoretical knowledge but lack practical experience. Therefore, their ability to cultivate innovative talents with both theoretical and practical abilities is limited. Third, most colleges and universities' assessment of teachers is still based on scientific research. This has caused many teachers to place emphasis on scientific research rather than teaching. Little effort has been devoted to the updating of teaching content and innovation of educational forms. Thus, the improvement of education quality is affected, and the goal of cultivating innovative talents is difficult to achieve.

\section{B. Outdated Innovation and Entrepreneurship Education Model}

In most colleges and universities, innovation and entrepreneurship education is still a kind of marginal education, which fails to truly integrate with the school's teaching system. The curriculum system of innovation and entrepreneurship education is incomplete, the syllabus is incomplete, the education model is outdated, and the education concept is not able to keep up with the times. The innovation and entrepreneurship education of many colleges and universities basically stays on books, focusing on indoctrination of professional theoretical knowledge, and ignoring the integration of theory with practice. This kind of education model that emphasizes "theory" and ignores "practice" is insufficient for the cultivation and guidance of student interest. It will not be able to stimulate the students' awareness of innovation and entrepreneurship, and their innovation and entrepreneurship abilities will not be improved.

\section{Undergraduates' Low Awareness of Innovation and Entrepreneurship}

In the process of innovation and entrepreneurship education of colleges and universities in Guangdong Province, college students are in a state of "high enthusiasm and low practice" for innovation and entrepreneurship. Some studies have shown that the proportion of college students in China choosing entrepreneurship is only 5\% per year. Compared with the developed countries of $20 \%-30 \%$ college students starting a business, there is still a large gap. The vast majority of college students have a weak sense of innovation and entrepreneurship. Although they have an entrepreneurial dream, they are more in pursuit of ease and still focus on employment. The main reasons for the lack of awareness of college students' innovation and entrepreneurship are as follows. First, college students need financial support for entrepreneurship. Many college students have just stepped into the society and lacked capital accumulation. Most college students start their business with funding from classmates' fund raising and financial support from colleges and universities. The inflow of social funds is relatively low, and the existence of thresholds for bank loans restricts college students from obtaining more financial support. Second, entrepreneurship is a high-risk job. Among the $5 \%$ of startups, the national average success rate for college students is only $3 \%$, and many worry about failure. Third, college students lack social experience and cannot solve some market problems.

\section{Colleges and Universities in Guangdong, Hong Kong and Macau Have Not Yet Established Close Cooperative Relations}

Due to the differences in the school running system, education system, policies, and training goals of colleges and universities in Guangdong, Hong Kong, and Macau, the educational cooperation among the three places has been based on the interests of all parties. Therefore, colleges and universities in Guangdong, Hong Kong, and Macau have not yet established close cooperative relations. Failure to play a synergistic role in the development of Guangdong, Hong Kong, and Macau in terms of personnel training, sharing of scientific and technological resources, integration of educational concepts, subject learning, and information exchange will not be conducive to the development of education in Guangdong, Hong Kong and Macau. The 
cooperation among Guangdong, Hong Kong, and Macau is basically carried out by non-governmental organizations. The cooperation and exchanges are relatively fragmented, limited to a certain project, and lack overall importance and long-term planning.

\section{COUNTERMEASURES TO PROMOTE INNOVATION EDUCATION OF COLLEGES AND UNIVERSITIES IN GUANGDONG PROVINCE}

\section{A. Strengthening the Construction of Innovative Education Tutors in Colleges and Universities}

The cultivation of innovative talents is inseparable from a stable team of innovative education mentors, and it is important to build a high-quality mentor team with innovative spirit, innovative ability and innovative experience. First of all is to solve the problem of shortage of innovative education tutors. Colleges and universities should actively adopt the strategy of "internal training and external introduction". Colleges and universities can establish an innovative education teacher training system, explore innovative teaching rules, strengthen teachers' recognition of innovative education through training, advanced studies, advanced studies and other forms, arrange teachers to learn from enterprises or scientific research units, and cultivate a batch of full-time teachers of innovative education. Colleges and universities should be effectively associated with society and enterprises, and government officials, corporate executives and other scholars with innovative and practical experience can be employed as part-time teachers. Secondly, colleges and universities should deepen the reform of teacher assessment and evaluation system, attach importance to teaching quality, and strengthen the evaluation of practical teaching links. Colleges and universities can also set up incentive mechanism for innovative education, so as to promote teachers to actively participate in the cultivation of innovative education for college students and improve the quality of innovative education.

\section{B. Reform and Innovation of Education Model}

The education model that emphasizes "theory" but not "practice" can only be a carrier of knowledge, and it is difficult to become a creator of knowledge. Therefore, colleges and universities must reform and innovate the education model. Innovation and entrepreneurship education should not be limited to indoctrination of theoretical knowledge. Colleges and universities should encourage the students to integrate theory with practice and actively carry out innovation and entrepreneurship projects. Colleges and universities should incorporate innovation and entrepreneurship education into the talent training system for professional education and cultural quality education, establish a multi-level and three-dimensional innovative curriculum system, attach importance to and implement educational concepts and implementations that are led by internship practice, and feature experiential training mode and implementation model. Colleges and universities can also innovate teaching methods based on their actual conditions, and comprehensively run teaching methods such as heuristic teaching, problem-based teaching, and project practice teaching to cultivate students' learning interest and stimulate students' creative ability.

\section{Strengthening the Innovation and Entrepreneurship Education for College Students and Promoting Colleges Students to Start Their Own Businesses}

There is a very important reason why the world-class greater bay area can maintain its international competitive advantage for a long time, that is, the replacement effect brought by the innovative and entrepreneurial activities of college students is conducive to the advanced development of industrial structure. In the context of the construction of the Guangdong-Hong Kong-Macao Greater Bay Area, colleges and universities in Guangdong Province should strengthen education on innovation and entrepreneurship for college students, increase their awareness of innovation and entrepreneurship, and promote college students' awareness of independent innovation and entrepreneurship. First of all, colleges and universities in Guangdong Province can strengthen the propaganda of entrepreneurship, advocate entrepreneurship spirit, educate students on the concept of entrepreneurship, and actively create an academic atmosphere of innovation and entrepreneurship, so as to make students deeply realize the importance and feasibility of innovation and entrepreneurship. At the same time, colleges and universities should cooperate with enterprises to hire well-known entrepreneurs as teachers of innovation and entrepreneurship, to teach college students' social management experience such as business management and marketing, and to encourage college students to actively participate in internships and accumulate social experience. Secondly, a reward and commendation system for student innovation and entrepreneurship should be set up to commend outstanding undergraduate entrepreneurs and give appropriate bonuses to encourage students to participate in innovation and entrepreneurship. Finally, colleges and universities should introduce some social resources, build a support system for college students' innovation and entrepreneurship funds, lower the threshold for college students' entrepreneurial loans, and allow more college students to have the opportunity to start their own businesses.

\section{Promoting In-depth Cooperation Among Colleges and Universities in Guangdong, Hong Kong and Macau}

In the context of the development of the GuangdongHong Kong-Macao Greater Bay Area, colleges and universities in Guangdong, Hong Kong and Macau should focus on the long-term and overall nature of cooperative development, and get rid of those short-sighted, selfinterested positions and practices in the past. The cooperation and development of colleges and universities in Guangdong, Hong Kong and Macau should follow the principle of seeking common ground while shelving differences, presenting a diverse and inclusive state of cooperation, and achieving win-win results through complementary advantages. The education level, teaching quality, and basic scientific research quality of Hong Kong and Macau are first-rate. In Hong Kong and Macau, there 
have many world-renowned universities, such as the University of Hong Kong, the Chinese University of Hong Kong, the Hong Kong University of Science and Technology, the University of Macau, and the Macau University of Technology. Guangdong Province has certain advantages in the quality of students, land resources, experimental bases, scientific research and development. The in-depth cooperation among colleges and universities in Guangdong, Hong Kong and Macau can take advantage of the resources to achieve complementary advantages and win-win situation, so as to promote the development of education and talents in the Guangdong-Hong Kong-Macao Greater Bay Area. At the same time, colleges and universities in Guangdong, Hong Kong and Macau should establish a clear strategic plan to promote the joint cultivation of talents, scientific research and academic exchanges among universities, establish scientific and technological research centers and cooperative laboratories, and establish and improve the incentive and evaluation mechanism for higher education cooperation by signing inter-university cooperation agreements. Colleges and universities can also carry out credit recognition for specific courses and implement more flexible exchange arrangements, so as to promote in-depth cooperation among universities in Guangdong, Hong Kong and Macau.

\section{CONCLUSION}

Colleges and universities in Guangdong Province should seize the opportunities brought by the development and construction of the Guangdong-Hong Kong-Macao Greater Bay Area, combine the characteristics and development of their own schools, strengthen the construction of innovative education teachers, continuously improve the relevant institutions of higher education, improve the quality of education, guide and encourage college students to make the innovation and entrepreneurship, actively participate in university cooperation, and provide more high-quality innovative talents for the economic development of the Guangdong-Hong Kong-Macao Greater Bay Area.

\section{REFERENCES}

[1] Zhu Hongbo. On the Importance of Cultivating Innovative Talents in the Institution of Higher Learning [J]. Journal of Guizhou University(Social Science), 2004 (2). (in Chinese)

[2] Liu Dinghui, Wang Chao, Liu Xiyuan. The Problems and Countermeasures of Cultivating College Students' Innovative Spirit against the Background of New Normal [J]. The Theory and Practice of Innovation and Entrepreneurship, 2018 (14). (in Chinese)

[3] Wu Handong, Yu Yang, Guo Xuesong, Wang Lijie, Zhang Zhen. Study on the Construction of Teaching Staff of Innovation and Entrepreneurship Education in Colleges and Universities [J]. Continue Education, 2015 (6). (in Chinese)

[4] Han Lina, Ruan Chuanyang.Cultivation of Innovation and Entrepreneurship Talents in Guangdong Colleges and Universities against the Background of Guangdong-Hong Kong-Macao Greater Bay Area [J]. Education Modernization, 2019 (5). (in Chinese)

[5] Xian Xuelin, An Dongping. Study on the current situation and cooperation pattern of higher education in Guangdong-Hong KongMacao Greater Bay [J]. Journal of Shenzhen Institute of Information Technology, 2017 (4). (in Chinese) 